\title{
ATP-Bioluminescence and Conventional Microbiology for Hygiene Evaluation of Cutting Room Surfaces in Poultry Slaughterhouse
}

\author{
Laura Beatriz Rodrigues',2, Luciana Ruschel dos Santos', Natalie Nadin Rizzo', Daiane Ferreira', \\ Amauri Picollo de Oliveira', Rafael Levandowski', Bruna Webber ${ }^{2}$ \& Vladimir Pinheiro do Nascimento²
}

\begin{abstract}
Background: The hygiene procedures in poultry slaughterhouses consist in the use of hot water, detergent and sanitizing, configuring Sanitation Standard Operating Procedure (SSOP). These actions control contamination in food processing environments, especially by pathogenic microorganisms, which cause diseases with impact on public health and economic losses. The microbiological control of aerobic mesophiles, Staphylococcus aureus and Escherichia coli, are used as indicators of contamination. The hygienic-sanitary conditions on the surfaces of the poultry slaughterhouse cuttting room were evaluated, before and after cleaning and sanitizing procedures.

Materials, Methods \& Results: Conventional microbiology (Rodac plates and sponge for quantification of aerobic mesophiles, Staphylococcus aureus and Escherichia coli) and ATP-Bioluminescence were used to analyze the action of hot water and the active principles peracetic acid, quaternary ammonia and biguanide in the standard pre-operational hygiene procedure in the cutting room of the poultry slaughterhouse under Federal Inspection with slaughter capacity of more than $20.000 \mathrm{birds} / \mathrm{h}$. The evaluations were performed on three lines of chicken thigh cuts at the same time and in a completely randomized manner on stainless steel surfaces, polyurethane belts and polyethylene boards. Samples were made in four replicates at the three surface totaling 108 assay for each microorganism. The samples were collected at the end of the cutting process, before and after washing the surfaces with hot water (between 45 and $50^{\circ} \mathrm{C}$ ) and after sanitization with $0.5 \%$ peracetic acid, $2 \%$ quaternary ammonia and $1 \%$ biguanide. The ATP-Bioluminescence method detected organic matter at all collected points and Rodac plates allowed a better recovery of microorganisms than sponges for quantification of aerobic mesophiles, E. coli and S. aureus. There was a reduction of contamination after the action of hot water and, after using quaternary ammonia and peracetic acid, there was no isolation of $E$. coli and $S$. aureus on all evaluated surfaces.

Discussion: The use of different methods of analysis for monitoring the hygiene and sanitary status of contact surfaces with chicken cuts allows greater flexibility in relation to hygiene control. The use of the bioluminescent ATP detection method allows detecting in seconds extremely low levels of contamination, allowing a quick determination of the cleaning efficiency on the surfaces and evaluation of the hygiene programs. Conventional microbiology methods, on the other hand, provide indicators of contamination by different microorganisms on food contact surfaces. Both are applicable in SSOP monitoring programs and sanitary conditions of the contact surfaces in food producing establishments. The significant reduction of microorganisms on surfaces after cleaning, found in this study, demonstrates the importance of operational hygiene in the maintenance of microbial contamination below the recommended limits, and to reconcile the ATP-Bioluminescence methodologies and Rodac plates can bring benefits to the control of this contamination, and the use of ATP-bioluminescence makes possible taking immediate corrective measures after the evaluation of sanitation procedures.
\end{abstract}

Keywords: ATP-Bioluminescence, Rodac plates, Escherichia coli, mesophiles, Staphylococcus aureus. 


\section{INTRODUCTION}

Pathogenic microorganisms are important because they cause foodborne diseases. The mesophilic aerobic bacteria are part of the family Enterobacteriaceae, and bacteria of the genera Staphylococcus, Streptococcus, and others [12]. Escherichia coli is the main representative of the fecal coliform group, used as indicators of fecal contamination and deficient hygienic-sanitary conditions $[5,9,15]$.

One of the ways of verifying the effectiveness of sanitation procedures is the Rodac plates method ("replicate organism detection and counting"), which allows the replication of organisms directly in agar after contact with the surface [9]. Tests using ATP-Bioluminescence are accepted as a method of monitoring the hygienic-sanitary status of food production lines by quantifying ATP. This technique detects microbial cells and food residues, which may persist after inadequate cleaning and be a source of nutrients for microbial multiplication $[1,3]$.

The objective of this study was to evaluate the hygienic-sanitary conditions of stainless steel table surfaces, polyurethane belts and polyethylene boards in a poultry slaughterhouse, using conventional microbiology (Rodac plates and sponge) and ATP-bioluminescence to analyze the effectiveness of hot water and three active principles (peracetic acid, quaternary ammonia and biguanide) in the hygiene process, quantifying aerobic mesophilic microorganisms, Staphylococcus aureus, Escherichia coli and ATP.

\section{MATERIALS AND METHODS}

\section{Sampling and collection}

The study carried out in the cutting room of a poultry slaughterhouse in the south of Brazil, with slaughter capacity of more than 20.000 birds/h. Samples were collected at the end of the cutting process in the pre-operational sanitation as follows: before washing the surfaces without the removal of waste; after washing with water between $45^{\circ} \mathrm{C}$ and $50^{\circ} \mathrm{C}$ and pressure of $22.5 \mathrm{bar}$; after washing with $2 \%$ sodium hydroxide base detergent (Power Foam ${ }^{\circledR}$, Johnson Diversey) ${ }^{1}$ with 10 min action, rinse with water between $45^{\circ} \mathrm{C}$ and $50^{\circ} \mathrm{C}$ and 22.5 bar pressure, and sanitize. Three active principles were tested: peracetic acid $0.5 \%$ (Divosan Forte $\left.{ }^{\circledR}\right)^{1}$, quaternary ammonia 2\% (Divosan Divoquat Forte $\left.{ }^{\circledR}\right)^{1}$ and biguanide $1 \%$ (Divosan Divosept $\left.350^{\circledR}\right)^{1}$, with $15 \mathrm{~min}$ action. The evaluations were performed in three lines of chicken thigh cuts at the same time and in a completely randomized manner, in four replicates for each surface: stainless steel tables, polyurethane belts and polyethylene boards, totaling 36 analyzes per sponge and 36 Rodac plates for quantification of Escherichia coli, Staphylococcus aureus and aerobic mesophilic microorganisms, in addition to 36 ATP-Bioluminescence assays, totaling 108 for each methodology/microorganism.

\section{Samples collected using sponge}

The collections were carried out with sponge (Laborclin ${ }^{\circledR}$ wipes) $)^{2}$, with $50 \mathrm{~mL}$ of $0.1 \%$ peptone water with neutralizer, rubbed onto the surfaces in an area of $100 \mathrm{~cm}^{2}$ delimited by sterile mold [7].

\section{Samples collected using agar in contact plates}

Sample collections of surfaces made with agar contact plates (Rodac with neutralizing lecithin and Tween 80), the plates were randomly distributed and each exposed agar maintained for $5 \mathrm{~s}$ under pressure in contact with the evaluated surface [7].

Samples collectec using swabs for ATP-Bioluminescence

The collections for this method was performed with specific swabs for bioluminescence ATP detection $(\text { Swabs LuciPac W })^{3}$, rubbed diagonally at an angle of $30^{\circ}$ with the surface in an area of $100 \mathrm{~cm}^{2}$, delimited by sterile mold [4].

All the collected samples were transported under refrigeration, in isothermal containers, to the laboratory.

Evaluation of contamination by conventional microbiology with sponge

Were added $50 \mathrm{~mL}$ of buffered peptone water $0.1 \%$ in sponge sachets (wipes, with neutralizers) ${ }^{2}$ and serial dilutions carried out $[7,16]$.

\section{Mesophilic aerobic microorganisms count}

After dilutions $10^{-1}, 10^{-2}$ and $10^{-3}$ were inoculated $0.5 \mathrm{~mL}$ on agar surface for counting (PCA $)^{2}$. Reading was performed after $48 \mathrm{~h}$ of incubation at $36 \pm 1^{\circ} \mathrm{C}$ and the results expressed in $\log _{10}$ UFC.cm ${ }^{-2}$ $[7,12,16]$.

Staphylococcus aureus count

Aliquots of $0.1 \mathrm{~mL}$ dilutions $10^{-1}, 10^{-2}$ and $10^{-3}$ were inoculated on the surface of Baird-Parker 
agar $\left(\text { Laborclin }^{\circledR}\right)^{2}$. Reading was performed after 30$48 \mathrm{~h}$ of incubation at $36 \pm 1^{\circ} \mathrm{C}$ and confirmation of S. aureus by biochemical tests (catalase, coagulase and DNAse). The results were expressed in $\log _{10} \mathrm{UFC}$. $\mathrm{cm}^{-2}[7,11]$.

Escherichia coli count

Aliquots of $0.5 \mathrm{~mL}$ dilutions $10^{-1}, 10^{-2}$ and $10^{-3}$ were inoculated on surface in Violet Red Bili Agar ${ }^{2}$. Reading was performed after 18-24 h of incubation at $36 \pm 1^{\circ} \mathrm{C}$. Typical colonies were confirmed by selective broths and biochemical tests for Escherichia coli (TSI, LIA, SIM, Citrato, VM, VP). Results were expressed in $\log _{10}$ UFC.cm ${ }^{-2}[7,10,16]$.

\section{Conventional microbiology tests with contact plates (Rodac)}

\section{Count of mesophilic aerobic microorganisms}

It was used PCA agar methodology with neutralizing agent in contact plates (Rodac) ${ }^{2}$. Reading was performed after $48 \mathrm{~h}$ of incubation at $36 \pm 1^{\circ} \mathrm{C}$ and results expressed in $\log _{10}$ UFC.cm ${ }^{-2}$ $[7,12,16]$.

Staphylococcus aureus count

It was used Baird-Parker agar with neutralizing agent in contact plates (Rodac - Laborclin $\left.{ }^{\circledR}\right)^{2}$. Reading was performed after $30-48 \mathrm{~h}$ of incubation at $36 \pm 1^{\circ} \mathrm{C}$ and confirmation of $S$. aureus by biochemical evidence already cited. Results were expressed in $\log _{10}$ UFC. $\mathrm{cm}^{-2}[7,11]$.
Escherichia coli count

It was made using Violet Red Bili Agar with neutralizers in contact plates (Rodac) ${ }^{2}$. Reading was performed after $18-24 \mathrm{~h}$ of incubation at $36 \pm 1^{\circ} \mathrm{C}$. Typical colonies were confirmed by biochemical tests for Escherichia coli and results expressed in $\log _{10}$ UFC.cm-2 $[7,10,16]$.

\section{ATP-Bioluminescência test}

The extremities of swabs (LuciPac W) ${ }^{3}$ were fragmented for the reagent to contact the sample and then to introduce into the luminometer for reading by light emission (Lumitester PD10N) ${ }^{3}$ with results expressed in $\log _{10}$ URL.cm ${ }^{-2}$.

\section{Statistical analysis}

Variance analysis was used for the randomized complete block and Tukey test with 5\% significance (COHort Software) $)^{4}$.

\section{RESULTS}

The ATP-Bioluminescence method detected organic matter at all points collected, independent of the performance of the hygiene process (Table 1). Use of Rodac plates allowed better recovery of microorganisms than the sponge for quantification of aerobic mesophiles (Table 2), E. coli (Table 3) and S. aureus (Table 4).

After the use of hot water, contamination was reduced and, after the use of quaternary ammonia and peracetic acid, there was no isolation of E. coli and S. aureus on all evaluated surfaces (Table 3 and Table 4).

Table 1. $\log _{10}$ URL.cm ${ }^{-2}$ of ATP on different surfaces on poultry slaughterhouse cutting room before hygiene, after washing with hot water and after sanitizers. Repetitions average.

\begin{tabular}{|c|c|c|c|}
\hline \multirow[b]{2}{*}{ Treatment } & \multicolumn{3}{|c|}{ Surfaces } \\
\hline & $\begin{array}{c}\text { Stainless Stell } \\
\text { Tables }\end{array}$ & $\begin{array}{l}\text { Polyethylene } \\
\text { Boards }\end{array}$ & $\begin{array}{c}\text { Polyurethane } \\
\text { Belts }\end{array}$ \\
\hline Before Cleaning & $2.29 \pm 0.94^{\mathrm{A} \mathrm{a}}$ & $2.01 \pm 0.43^{\mathrm{AB} a}$ & $1.63 \pm 0.86^{\mathrm{B} \mathrm{a}}$ \\
\hline After Hot Water & $1.20 \pm 1.34^{\mathrm{Ab}}$ & $0.87 \pm 0.76^{\mathrm{Ab}}$ & $0.93 \pm 0.72^{\mathrm{Abc}}$ \\
\hline Peracetic Acid & $0.50 \pm 0.71^{\mathrm{AB} b c d}$ & $0.32 \pm 0.71^{\mathrm{B} \mathrm{bc}}$ & $1.42 \pm 0.50^{\mathrm{A} a b}$ \\
\hline Quaternary Ammonia & $-0.12 \pm 0.48^{\mathrm{Ad}}$ & $0.33 \pm 0.52^{\mathrm{Abc}}$ & $0.52 \pm 0.45^{\mathrm{Abc}}$ \\
\hline Biguanide & $1.10 \pm 0.22^{\mathrm{Abc}}$ & $-0.57 \pm 0.59^{\mathrm{B} \mathrm{c}}$ & $0.21 \pm 1.03^{\mathrm{AB} \mathrm{C}}$ \\
\hline
\end{tabular}


Table 2. Use Rodac plates and sponge to evaluate count aerobic mesophilic microorganisms from different surfaces on poultry slaughterhouse cutting room before hygiene, after washing with hot water and after sanitizers. Repetitions average.

\begin{tabular}{|c|c|c|c|c|c|c|}
\hline \multirow{3}{*}{ Treatment } & \multicolumn{6}{|c|}{ Surfaces } \\
\hline & \multicolumn{2}{|c|}{$\begin{array}{c}\text { Stainless Stell } \\
\text { Tables } \\
\left(\log _{10} \cdot \text { UFC.cm-2) }\right.\end{array}$} & \multicolumn{2}{|c|}{$\begin{array}{c}\text { Polyethylene } \\
\text { Boards } \\
\left(\log _{10} . \mathrm{UFC} \cdot \mathrm{cm}^{-2}\right) \\
\end{array}$} & \multicolumn{2}{|c|}{$\begin{array}{c}\text { Polyurethane } \\
\text { Belts } \\
\left(\log _{10} \cdot \text { UFC.cm解) }\right.\end{array}$} \\
\hline & Rodac & Sponge & Rodac & Sponge & Rodac & Sponge \\
\hline $\begin{array}{l}\text { Before } \\
\text { cleaning }\end{array}$ & $2 \pm 0^{\mathrm{AB} \mathrm{a}}$ & $-0.46 \pm 4.20^{\mathrm{CD} \mathrm{a}}$ & $2 \pm 0^{\mathrm{AB} \mathrm{a}}$ & $2.59 \pm 1.85^{\mathrm{A} \mathrm{a}}$ & $1.23 \pm 1.04^{\mathrm{ABC} a}$ & $-1.45 \pm 1.67^{\mathrm{Da}}$ \\
\hline $\begin{array}{l}\text { After Hot } \\
\text { Water }\end{array}$ & $-0.48 \pm 1.82^{\mathrm{BC} b c}$ & $-1.53 \pm 1.15^{\mathrm{Ca}}$ & $2 \pm 0^{\mathrm{Aa}}$ & $-0.51 \pm 3.07^{\mathrm{BC} \mathrm{b}}$ & $1.05 \pm 1.83^{\mathrm{AB} \mathrm{a}}$ & $-1.69 \pm 0^{\mathrm{Ca}}$ \\
\hline $\begin{array}{c}\text { Peracetic } \\
\text { Acid }\end{array}$ & $-1.84 \pm 0.60^{\mathrm{Ac}}$ & $-1.19 \pm 2^{\mathrm{Aa}}$ & $-2 \pm 0^{\mathrm{Ab}}$ & $-1.69 \pm 0^{\mathrm{Ab}}$ & $-0.12 \pm 1.55^{\mathrm{Aa}}$ & $-1.69 \pm 0^{\mathrm{A} \mathrm{a}}$ \\
\hline $\begin{array}{l}\text { Quaternary } \\
\text { Ammonia }\end{array}$ & $-0.58 \pm 2.22^{\mathrm{Abc}}$ & $-1.69 \pm 0^{\mathrm{Aa}}$ & $-2 \pm 0^{\mathrm{Ab}}$ & $-0.80 \pm 3.56^{\mathrm{Ab}}$ & $-0.48 \pm 1.55^{\mathrm{Aa}}$ & $-1.19 \pm 2^{\mathrm{Aa}}$ \\
\hline Biguanide & $-0.20 \pm 2.06^{\mathrm{Abc}}$ & $-0.62 \pm 2.49^{\mathrm{A} \mathrm{a}}$ & $-0.26 \pm 1.08^{\mathrm{Ab}}$ & $-1.69 \pm 0^{\mathrm{Ab}}$ & $0.45 \pm 2.12^{\mathrm{Aa}}$ & $-0.46 \pm 2.86^{\mathrm{Aa}}$ \\
\hline
\end{tabular}

Table 3. Use Rodac plates and sponge for evaluation of Escherichia coli count different surfaces on poultry slaughterhouse cutting room before hygiene, after washing with hot water and after sanitizers. Repetitions average.

\begin{tabular}{|c|c|c|c|c|c|c|}
\hline \multirow{3}{*}{ Treatment } & \multicolumn{6}{|c|}{ Surfaces } \\
\hline & \multicolumn{2}{|c|}{$\begin{array}{c}\text { Stainless Stell } \\
\text { Tables } \\
\left(\log _{10} \cdot \text { UFC.cm }{ }^{-2}\right) \\
\end{array}$} & \multicolumn{2}{|c|}{$\begin{array}{c}\text { Polyethylene } \\
\text { Boards } \\
\left(\log _{10} \text { UFC.cm }{ }^{-2}\right)\end{array}$} & \multicolumn{2}{|c|}{$\begin{array}{c}\text { Polyurethane } \\
\text { Belts } \\
\left(\log _{10} . \text { UFC.cm-2 }\right) \\
\end{array}$} \\
\hline & Rodac & Sponge & Rodac & Sponge & Rodac & Sponge \\
\hline $\begin{array}{c}\text { Before } \\
\text { Cleaning }\end{array}$ & $-0.33 \pm 4.11^{\mathrm{Aa}}$ & $-1.69 \pm 0^{\mathrm{B} \mathrm{a}}$ & $-2 \pm 0^{\mathrm{B} a}$ & $-1.69 \pm 0^{\mathrm{B} \mathrm{a}}$ & $-2 \pm 0^{\mathrm{B} \mathrm{a}}$ & $-1.69 \pm 0^{\mathrm{B}}$ \\
\hline $\begin{array}{l}\text { After Hot } \\
\text { Water }\end{array}$ & $-2 \pm 0^{\mathrm{Ab}}$ & $-1.69 \pm 0^{\mathrm{Aa}}$ & $-1.66 \pm 2.30^{\mathrm{Aa}}$ & $-1.69 \pm 0^{\mathrm{Aa}}$ & $-1.89 \pm 0.69^{\mathrm{A} a}$ & $-1.69 \pm 0^{\mathrm{A}}$ \\
\hline $\begin{array}{c}\text { Peracetic } \\
\text { Acid }\end{array}$ & $-2 \pm 0^{\mathrm{Ab}}$ & $-1.69 \pm 0^{\mathrm{Aa}}$ & $-2 \pm 0^{\mathrm{Aa}}$ & $-1.69 \pm 0^{\mathrm{Aa}}$ & $-2 \pm 0^{\mathrm{Aa}}$ & $-1.69 \pm 0^{\mathrm{A}}$ \\
\hline $\begin{array}{l}\text { Quaternary } \\
\text { Ammonia }\end{array}$ & $-2 \pm 0^{\mathrm{Ab}}$ & $-1.69 \pm 0^{\mathrm{Aa}}$ & $-2 \pm 0^{\mathrm{Aa}}$ & $-1.69 \pm 0^{\mathrm{Aa}}$ & $-2 \pm 0^{\mathrm{Aa}}$ & $-1.69 \pm 0^{\mathrm{A}}$ \\
\hline Biguanide & $-2 \pm 0^{\mathrm{Ab}}$ & $-1.69 \pm 0^{\mathrm{A} \mathrm{a}}$ & $-1.69 \pm 1.20^{\mathrm{A} \mathrm{a}}$ & $-1.69 \pm 0^{\mathrm{A} \mathrm{a}}$ & $-1.77 \pm 0.90^{\mathrm{A} \mathrm{a}}$ & $-1.69 \pm 0^{\mathrm{A}}$ \\
\hline
\end{tabular}

Means followed by the same letters, lowercase in rows and uppercase in columns, do not differ amongst themselves $(P \leq 0.05)$ by Tukey's test.

Table 4. Use of Rodac plates and sponge for evaluation of Staphylococcus aureus count in $\log _{10}$ UFC.cm-2 prior to sanitization, after washing with hot water and after the sanitizers. Repetitions average.

\begin{tabular}{ccc}
\hline Treatment & \multicolumn{2}{c}{ Methodologies } \\
\cline { 2 - 3 } & Rodac & Sponge \\
\hline Before Cleaning & $-0.99 \pm 2.93^{\mathrm{A} \mathrm{a}}$ & $-1.00 \pm 0^{\mathrm{Aa}}$ \\
After Hot Water & $-1.89 \pm 0.85^{\mathrm{B} \mathrm{b}}$ & $-1.00 \pm 0^{\mathrm{A} \mathrm{a}}$ \\
Peracetic Acid & $-2.00 \pm 0^{\mathrm{B} \mathrm{b}}$ & $-1.00 \pm 0^{\mathrm{A} \mathrm{a}}$ \\
Quaternary Ammonia & $-2.00 \pm 0^{\mathrm{B} \mathrm{b}}$ & $-1.00 \pm 0^{\mathrm{A} \mathrm{a}}$ \\
Biguanide & $-2.00 \pm 0^{\mathrm{B} \mathrm{b}}$ & $-1.00 \pm 0^{\mathrm{A} \mathrm{a}}$ \\
\hline
\end{tabular}

Means followed by the same letters, lowercase in rows and uppercase in columns, do not differ amongst themselves $(P \leq 0.05)$ by Tukey's test. 


\section{DISCUSSION}

At stainless steel tables, before cleaning, a statistical difference was obtained in average ATP, demonstrating that both hot water and sanitizers reduced organic load on this surface. Water action between 45 and $50^{\circ} \mathrm{C}$ in polyethylene plates to reduce ATP was similar to peracetic acid and to quaternary ammonia, with significant difference only for biguanide, which determined a greater reduction of ATP in these surfaces (Table 1).

ForATP analysis, there is a recommendation that, after hygiene, the maximum value is $1 \log _{10}$ URL.cm ${ }^{-2}$ [17] and the action of hot water on operational hygiene was sufficient to reach these levels in belts and polyethylene plates. However, only after using of quaternary ammonia it was possible to verify results below $1 \log _{10}$ URL.cm ${ }^{-2}$ on all tested surfaces. The recommendations of the manufacturer of the equipment used have as reference for reading ATP-Bioluminescence on surfaces the following measures: less than 50 URL $\left(1.7 \log _{10}\right)$ considered clean; from 50 to 200 URL (1.70-2.30 $\log _{10}$ ) contamination, probably without bacterial multiplication; from 200 to 500 URL (2.30-2.70 $\left.\log _{10}\right)$ slightly contaminated surface, with contamination susceptible to bacterial multiplication in days; above 500 URL (> $2.70 \log _{10}$ ) dirty and contaminated surface [1]. However, by the ATP-bioluminescence method, extremely low levels of contamination can be detected in seconds, allowing a quick determination of cleaning efficiency on surfaces and evaluation of the hygiene programs.

The cleaning and sanitizing process used in the cutting room evaluated in this work was effective, since the contamination related to aerobic mesophilic microorganisms was less than $1 \log _{10}$ UFC.cm ${ }^{-2}$ after using sanitizers in all evaluated points. These results are in accordance with Decision 471 of European Community [2], which recommends mesophilic levels between 0 to 10 UFC. $\mathrm{cm}^{-2}$ after SSOP, that is, up to $1 \log _{10}$ UFC.cm ${ }^{-2}$. This regulation describes contact plates, swabs and/or ISO methods for collecting meat processing surfaces after cleaning and disinfection. It should be noted that, after using of hot water, there was lower contamination than that recommended by this standard, prior to sanitization, in points such as stainless steel table.

There was isolation of E. coli on Rodac plates before cleaning on stainless steel table and, after using hot water and sanitizers, there was no recovery of this microorganism, demonstrating the action of these pro- cesses. However, it was not possible to recover E. coli before cleaning polyethylene and polyurethane surfaces, probably due to contamination on Rodac plates from these locations, hampering the isolation of pure colonies of E. coli. After using hot water there was isolation of E. coli on two surfaces, as well as the use of biguanide, demonstrating the ineffectiveness of this active principle on this agent under the conditions tested. However, there was no recovery of $E$. coli after the action of peracetic acid and quaternary ammonia. There was also no isolation of $E$. coli via sponges, probably due to low number of these bacteria on the surfaces sampled.

Variance analysis did not reveal interaction between surfaces and treatments and between surfaces and methodologies for quantification of Staphylococcus aureus $(P<0.05)$. Since there was recovery of $S$. aureus after hot water use, but not after sanitization, it is possible to infer the action of these products in reduction of the microorganism, detected by methodology with plates Rodac.

Significant reduction microorganisms on surfaces after cleaning, found in this study, demonstrates the importance of operational hygiene in maintaining microbial contamination below recommended limits. Gibson et al. [8], evaluating cleaning effect with detergents and water at room temperature with different pressures in a food industry observed reduction in contamination on surfaces of $1 \log _{10}$. Dunsmore et al. [6], observed a $99.8 \%$ reduction (approximately $3 \log _{10}$ ) after cleaning with detergents and water under pressure on stainless steel surfaces. In present study, surface contamination was reduced from 1 to $3 \log _{10}$ after cleaning only with water between $45^{\circ} \mathrm{C}$ and $50^{\circ} \mathrm{C}$ and pressure of 22.5 bar, in the majority of the evaluated points, mainly of aerobic mesophilic microorganisms.

Evaluated disinfectants (quaternary ammonia, peracetic acid and biguanide) are commonly used in the sanitization of the cutting room in refrigerators in Brazil $[1,13]$. The results prove that there was no significant difference in evaluated points, with all surfaces presenting contamination lower than that recommended by European Norm in relation to aerobic mesophiles.

\section{CONCLUSION}

The use of different methods to monitor hygienic-sanitary status of food contact surfaces makes it possible to make decisions regarding possible divergence in the control of hygiene. ATP-Biolumi- 
nescence presents immediate data on hygiene action, while conventional microbiology provides indicators of microbiological contamination on these surfaces. Conciliate these methodologies will bring benefits to sanitary control in poultry slaughterhouses by directing as corrective measures after hygiene evaluation.

\section{MANUFACTURERS}

${ }^{1}$ Johnson Diversey Inc. Charlotte, NC, USA.

${ }^{2}$ Laborclin. Pinhais, PR, Brazil.
${ }^{3}$ Kikkoman. Noda, Chiba, Japan.

${ }^{4}$ COHort Software. San Diego, CA, USA.

Acknowledgments. To Professor Carlos Costa and Luiz Florindo Castoldi for the assistance in statistical analysis. To professionals Graciela Trenhago, Jucenara Soares and Vinícius Zancanaro Tagliari, for laboratory assistance.

Declaration of interest. The authors report no conflicts of interest. The authors alone are responsible for the content and writing of the paper.

\section{REFERENCES}

1 Andrade N.J. 2008. Higiene na indústria de alimentos: avaliação e controle da adesão e formação de biofilmes bacterianos. São Paulo: Varela, pp.78-125.

2 European Community (EC). 2001. Decisão 471 de 08 de junho de 2001. Estabelece Regras para os Controles Regulares à Higiene Geral Efetuada pelos Operadores aos Estabelecimentos Exportadores de Carne. EC, 6p.

3 Corbitt A.J., Bennion N. \& Forsythe S.J. 2000. Adenylate kinase amplification of ATP-bioluminescence for hygiene monitoring in the food and beverage industry. Letters in Applied Microbiology. 30: 443-447.

4 Costa P.D., Andrade N.J., Soares N.F.F., Passos F.J.V. \& Brandão S.C.C. 2006. ATP-bioluminescence assay as an alternative for hygiene-monitoring procedures of stainless steeel milk contact surfaces. Brazilian Journal of Microbiology. 37: 345-349.

5 Delazari I. 1998. Aspectos microbiológicos ligados a segurança e qualidade da carcaça de aves. In: Anais da Semana Acadêmica Veterinária v.8. (São Paulo, Brazil). pp.71-77.

6 Dunsmore D.G., Twomex A., Whittlestone W.G. \& Morgan H.W. 1981. Design and performance of systems for cleaning product contact surfaces of food equipment: a review. Journal of food protection. 44: 220-240.

7 Evancho G.M., Sveum W.H., Moberg L.J. \& Frank J.F. 2001. Microbiological monitoring of the food processing environment. In: Downes F.P. \& Ito K. (Eds). Compendium of methods for the microbiological examination of foods. 4th edn. Washington: American Public Health Association, pp.25-35.

8 Gibson H., Taylor J.H., Hall K.E. \& Holah J.T. 1999. Effectiveness of cleaning techniques used in the food industry in terms of the removal of bacterial biofilms. Journal of applied microbiology. 87: 41-48.

9 Jay J.M. 2005. Microbiologia de alimentos. 6.ed. Porto Alegre: Artmed, 711p.

10 Kornacki J.L. \& Johnson J.L. 2001. Enterobacteriaceae, coliforms, and Escherichia coli as quality and safety indicators. In: Downes F.P. \& Ito K. (Eds). Compendium of methods for the microbiological examination of foods. 4th edn. Washington: American Public Health Association, pp.69-82.

11 Lancette G.A. \& Bennett R.W. 2001. Staphylococcus aureus and staphylococcal enterotoxins. In: Downes F.P. \& Ito K. (Eds). Compendium of methods for the microbiological examination of foods. 4th edn. Washington: American Public Health Association, pp.387-403.

12 Morton R.D. 2001. Aerobic plate count. In: Downes F.P. \& Ito K. (Eds). Compendium of methods for the microbiological examination of foods. 4th edn. Washington: American Public Health Association, pp.63-67.

13 Rech C.R., Brabes K.C.S., Buschinelli de Goes R.H.T., Aliatii L.N.S., Silva K.E., Ortolani L.G. \& Negrão F.J. 2016. Adesão e formação de biofilme de Escherichia coli em poli (tereftalato de etileno) e resistência a sanificantes. Evidência. 16(2): 113-130.

14 Rode T.M., Langsrud S., Holck A. \& Moretro T. 2007. Different patterns of biofilm formation in Staphylococcus aureus under food-related stress conditions. International Journal of Food Microbiology. 116(3): 372-383.

15 Siqueira R.S. 1995. Manual de microbiologia de alimentos. Brasília: EMBRAPA. 159p.

16 Swanson K.M.J., Petran R.L. \& Hanlin J.H. 2001. Culture methods for enumeration of microorganisms. In: Downes F.P. \& Ito K. (Eds). Compendium of methods for the microbiological examination of foods. 4th edn. Washington: American Public Health Association, pp.53-62.

17 Ukuku D.O., Pilizota V. \& Sapers G.M. 2001. Bioluminescence ATP assay for estimating total plate counts of surface microflora of whole cantaloupe and determining efficacy of washing treatments. Journal of Food Protection. 64: 813-819. 